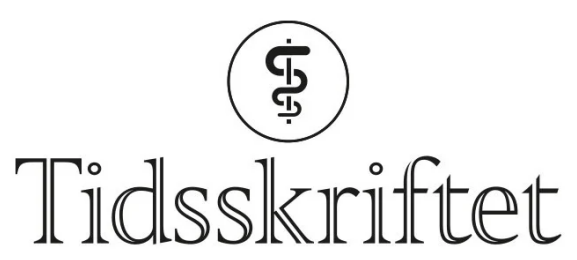

DEN NORSKE LEGEFORENING

\title{
Pulmonal tularemi
}

\author{
KORT KASUISTIKK
}

\section{ASTRID KRAVDAL}

astrid.kravdal@sykehuset-innlandet.no

Medisinsk avdeling

Sykehuset Innlandet, Gjøvik

Astrid Kravdal er spesialist i indremedisin og lungesykdommer og overlege.

Forfatteren har fylt ut ICMJE-skjemaet og oppgir ingen interessekonflikter.

\section{ØYSTEIN OLAV STUBHAUG}

Medisinsk avdeling

Sykehuset Innlandet, Gjøvik

Øystein Olav Stubhaug er spesialist i indremedisin og lungesykdommer og overlege.

Forfatteren har fylt ut ICMJE-skjemaet og oppgir ingen interessekonflikter.

\section{RUTA PIEKUVIENE}

Radiologisk avdeling

Sykehuset Innlandet, Gjøvik

Ruta Piekuviene er radiolog og avdelingsoverlege.

Forfatteren har fylt ut ICMJE-skjemaet og oppgir ingen interessekonflikter.

\section{ASTRID SANDNES}

Medisinsk avdeling

Sykehuset Innlandet, Gjøvik

Astrid Sandnes er konstituert overlege.

Forfatteren har fylt ut ICMJE-skjemaet og oppgir ingen interessekonflikter.

\section{Diagnostikk av tularemi, på norsk harepest, kan være vanskelig. Denne kasuistikken viser at pulmonal tularemi kan være en aktuell differensialdiagnose til lungekreft ved bildeundersøkelser.}

En mann i 5o-årene kontaktet legekontoret grunnet feber, redusert allmenntilstand og tørrhoste. Initial utredning med luftveis-PCR for SARS-CoV-2 var negativ. Han fikk først legetime tre uker etter sykdomsdebut. Han hadde da tørrhoste og uttalt nattesvette, men var blitt afebril. Han var tidligere røyker med rundt 20 pakkeår. Han hadde en stabil, medikamentelt behandlet epilepsi, men var ellers frisk. Klinisk undersøkelse var normal. Laboratorieprøver viste CRP $48 \mathrm{mg} / \mathrm{L}($ referanseverdi $<5$ ) og leukocytter innenfor 
referanseverdi. Røntgen toraks viste flekkede fortetninger i høyre overlapp og midtlapp. Ved kontroll fire uker etter symptomdebut hadde han fortsatt nattesvette, men ikke tørrhoste. CRP var da $22 \mathrm{mg} / \mathrm{L}$.

Gjennomgått pneumoni ble vurdert som en mulig diagnose, men grunnet vedvarende nattesvette henviste allmennlegen til CT toraks og abdomen. Bildene viste betydelig mediastinal lymfadenopati og to konsoliderte fortetninger i høyre lunge. Det var sentralt henfall både i fortetningene og lymfeknutene (Figur 1). Funnene ble beskrevet som malignitetssupekte, og fyldige binyrer ble oppfattet som mulige binyremetastaser. Pasienten ble derfor henvist til lokalsykehuset som pakkeforløp lungekreft.

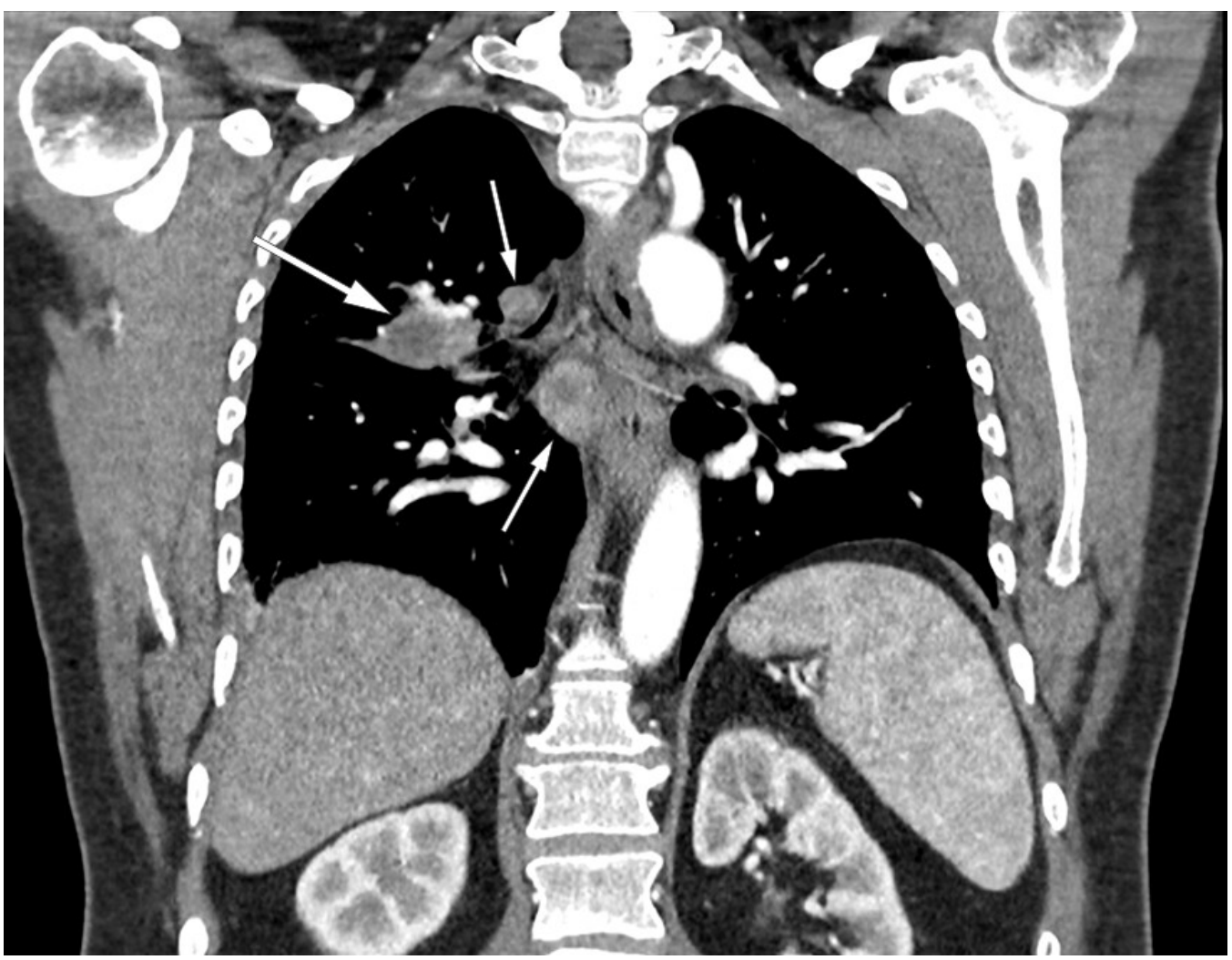

Figur 1 Koronal CT toraks med kontrast av pasient med pulmonal tularemi viser sentralt henfall både i utbredt lymfadenopati (små piler) og i konsolidert fortetning hilusnært høyre side (stor pil).

Ved vurdering på lokalsykehuset seks uker etter sykdomsdebut var han engstelig grunnet de radiologiske funnene, men følte seg ellers frisk. Han hadde ingen hoste eller nattesvette. Han opplyste nå at vekten var normalisert etter at han hadde hatt et vekttap på $10 \mathrm{~kg}$ under sykdomsforløpet. Klinisk undersøkelse var normal. Labratorieprøver viste CRP $11 \mathrm{mg} / \mathrm{L}$. Den betydelige kliniske bedringen kunne tyde på infeksiøs årsak. Vi har de siste årene sett liknende bildefunn hos pasienter med pulmonal tularemi. Det kom fram at han dagen før innsykning ryddet $i$ en gammel vedhaug hvor det var muselort. Serologi var positiv for både Francisella tularensis IgM og IgG, som bekreftet diagnosen pulmonal tularemi. Han fikk behandling med ciprofloksasin $500 \mathrm{mg} \times 2$ peroralt i ti dager. CT binyrer viste funn forenlig med binyreadenomer. Ved kontroll fire måneder etter sykdomsdebut var han helt restituert, og røntgen toraks var normal.

\section{Diskusjon}

Tularemi, på norsk harepest, er en zoonose forårsaket av bakterien Francisella tularensis. Det finnes tre ulike biovarianter av bakterien. I Norge forekommer kun F.tularenis subsp. holarctica. For harer er tularemi som regel dødelig, mens gnagere kan overleve lenge og være smittereservoar. Avhengig av det kliniske bildet og sted for inokulering, inndeles sykdommen i ulceroglandulær, glandulær, oculoglandulær, orofaryngeal, pulmonal og 
tyføs tularemi. Pulmonal tularemi skyldes vanligvis inhalasjon av F. tularensis. Den infeksiøse dosen er veldig liten. Ved aerosolsmitte er 10-25 bakterier nok til å gi sykdom. Inkubasjonstiden er vanligvis 3-5 dager, men kan variere fra 1-21 dager (1-3). Da vi ikke fikk frem annen eksponering enn vedrydding, antar vi at pasienten hadde en uvanlig kort inkubasjonstid og ble smittet dagen før innsykning. Det er sannsynligvis blitt dannet aerosoler av F. tularensis fra gnagerekskrementer under vedrydding. Aktiviteter som jakt, friluftsliv, gårdsarbeid, vedhogst og restaurering av gamle hus er kjente smitteveier. Det er derfor svært viktig med god anamnese av aktiviteter og fritidsreiser $(\mathbf{1}, 4,5)$. Likeledes er det viktig å informere befolkningen om forebyggende tiltak. Det anbefales å bruke hansker om man må ta i gnagere eller selvdøde harer. Man bør fjerne muselort med fuktig klut fremfor feiekost. Det bør også vurderes bruk av åndedrettsvern ved håndtering av materialer og liknende der man observerer gnagerekskrementer $(3,5)$.

Tularemi er meldepliktig til Folkehelseinstituttets meldesystem for smittsomme sykdommer (MSIS). Norge er blant de landene i verden med høyest forekomst av tularemi, og det er en økende trend i meldte tilfeller. Tularemi blir påvist i alle landets fylker, men hyppigst på Østlandet og i Trøndelag. Orofaryngeal og ulceroglandulær tularemi refereres som vanligst, men det finnes ingen offentlig statistikk på utbredelsen av de kliniske manifestasjonene (3). Pulmonal tularemi utgjorde nær halvparten av tularemitilfellene i en nyere observasjonsstudie fra Innlandet, presentert av vår gruppe (4). Sannsynligvis er pulmonal tularemi underdiagnostisert, og bør hyppigere vurderes som en differensialdiagnose (3). Sykdommen er vanligst om høsten. Høstsesongen krever derfor ekstra årvåkenhet $(\underline{4}, \underline{6})$.

Pulmonal tularemi gir typisk feber og generell sykdomsfølelse, eventuelt også luftveissymptomer $(\underline{1}, \underline{2}, \underline{4}, \underline{6})$. Vår erfaring fra rundt 40 tilfeller de siste årene, er at pasientene ofte har redusert allmenntilstand i flere uker. Dette er også beskrevet i flere kasuistikker (5,7.). Tularemi kan påvises ved både serologi, PCR eller dyrkning. Grunnet tilgjengelighet og høy sensitivitet, er serologi hjørnesteinen i diagnostikken. Det er imidlertid viktig å være klar over at antistoffresponsen, både IgM og IgG, er sen - gjerne først to til fire uker etter symptomdebut $(\underline{1}, \underline{2}, \underline{8})$. Ved negativ serologi, men fortsatt klinisk mistanke, anbefaler vi derfor at unders $\emptyset$ kelsen gjentas.

På røntgen toraks ser man ved pulmonal tularemi typisk fortetninger og hilær lymfadenopati. CT toraks viser oftest forstørrede lymfeknuter og konsoliderte, nodulære fortetninger, gjerne perifere og multiple. Et karakteristisk trekk er at lymfeknuter og fortetninger ofte har sentralt henfall, som hos vår pasient $(4, \underline{6}$, ,9.). Den differensialdiagnostiske utfordringen overfor malignitet, og spesielt lungekreft, er kjent fra litteraturen $(4,5,7.7$.) Det er derfor viktig at radiologer blir informert om eventuell infeksjonsklinikk.

Det er belastende for pasientene å bli henvist som pakkeforløp lungekreft. Dessverre gjennomgår disse pasientene ofte unødvendige, risikofylte og kostnadskrevende undersøkelser som PET-CT, CT-veiledet biopsi, bronkoskopi og endobronkial ultralyd (4). Vi mener nøkkelen til rask og effektiv diagnostikk er å vurdere pulmonal tularemi som en differensialdiagnose på et tidlig stadium, og spesielt hvis pasienten bor i eller har besøkt rurale områder. Serologi kan rekvireres både i primær- og spesialisthelsetjenesten. Serologi er en enkel metode for å bekrefte diagnosen i tilfeller der radiologi og sykehistorie gir mistanke om pulmonal tularemi.

Pasienten har gitt samtykke til at artikkelen blir publisert.

Takk til Aleris Røntgen for utlån av bilder.

1. Tärnvik A, Berglund L. Tularaemia. Eur Respir J 2003; 21:361-73. [PubMed][CrossRef] 
2. WHO guidelines on tularemia. Geneve: World Health Organization, 2007.

https://www.who.int/csr/resources/publications/WHO_CDS_EPR_2007_7.pdf?ua=1 Lest 11.2.2021.

3. Folkehelseinstituttet. Smittevernveilederen. Tularemi (harepest)-veileder for helsepersonell. https://www.fhi.no/nettpub/smittevernveilederen/sykdommer-a-a/tularemi---veileder-forhelseperson/ Lest 11.2.2021.

4. Kravdal A, Stubhaug $\emptyset 0$, Wåg $\emptyset$ AG et al. Pulmonary tularaemia: a differential diagnosis to lung cancer. ERJ Open Res 2020; 6: 00093-02019. [PubMed][CrossRef]

5. Hillerdal G, Kölbeck K, Jacobsson H. Lungtularemi: ovanlig sjukdom som kan tolkas som lungcancer. Serologi ger rätt diagnos, visar fallbeskrivningar. Lakartidningen 2013; 110: 1280-1. [PubMed]

6. Väyrynen SA, Saarela E, Henry J et al. Pneumonic tularaemia: experience of 58 cases from 2000 to 2012 in Northern Finland. Infect Dis (Lond) 2017; 49: 758-64. [PubMed][CrossRef]

7. Fachinger P, Tini GM, Grobholz R et al. Pulmonary tularaemia: all that looks like cancer is not necessarily cancer - case report of four consecutive cases. BMC Pulm Med 2015; 15: 27. [PubMed] [CrossRef]

8. Tärnvik A, Chu MC. New approaches to diagnosis and therapy of tularemia. Ann N Y Acad Sci 2007; 1105:378-404. [PubMed][CrossRef]

9. Rubin SA. Radiographic spectrum of pleuropulmonary tularemia. AJR Am J Roentgenol 1978; 131: 277-81. [PubMed][CrossRef]

Publisert: 20. juli 2021. Tidsskr Nor Legeforen. DOI:10.4045/tidsskr.21.0245

Mottatt 24.3.2021, første revisjon innsendt 23.5.2021, godkjent 30.5.2021.

Publisert under åpen tilgang CC BY-ND. Lastet ned fra tidsskriftet.no 26. april 2023. 